\title{
Grafts of Woody Plants and the Problem \\ of Incompatibility Between Scion and Rootstock (a review)
}

\author{
Julia A. Darikova*a, \\ Yulia V. Savva ${ }^{a}$, Eugene A. Vaganova, \\ Alexi M. Grachev ${ }^{a}$ and Galina V. Kuznetsovab \\ a Siberian Federal University, \\ 79 Svobodny, Krasnoyarsk, 660041 Russia \\ ${ }^{b}$ V.N. Sukachev Institute of Forestry of the Siberian Branch \\ of the Russian Academy of Sciences, \\ 50 Akademgorodok, Krasnoyarsk, 660036 Russia ${ }^{1}$
}

Received 4.03.2011, received in revised form 11.03.2011, accepted 18.03.2011

Grafting can occur naturally between branches or more often roots of the same species, or artificially via asexual propagation where the tissues of two plants are encouraged to fuse with one another. Artificial grafting is commonly used for propagation to improve qualities of trees grown commercially via selecting for its roots (called the rootstock) and for stem, leaves, flowers or fruits (called the scion). It is often used to reduce the time to flowering and shorten the breeding program, improve quality and yield of fruits and seeds, improve hardiness in response to environmental conditions and pathogens resistance, and change cultivars. Incompatibility between rootstock and scion has been more often observed for inter-specific than intraspecific grafts, and might result in a dieback of a graft. The objective of this paper was to review the recent literature related to graft applications and incompatibility between scion and rootstock. Anatomical studies of incompatible grafts demonstrated a poor vascular connection, vascular discontinuity and phloem degeneration at the union area, which might be detected as early as few weeks after a graft establishment. These vascular fusion problems can disturb water, nutrient and assimilate flows in the plant and might result in a further breakdown of a union area. Incompatibility might be also a result of insufficient plasmodesmatal coupling at an early stage of development within one of the graft partners. Differences in abundance of phenol compounds and starch below and above the graft union, as well as peroxidase amount at the union might serve as biochemical markers of the rootstock/scion incompatibility. Genetically and biochemically similar scions and rootstocks could improve graft compatibility.

Keywords: scion, rootstock, graft, compatibility.

* Corresponding author E-mail address: jualeksa@rambler.ru

(C) Siberian Federal University. All rights reserved 


\section{Introduction}

Grafts are often used in agriculture to select for and maintain desirable traits. Vegetative propagation such as grafting is preferable to sexual propagating to ensure reliability and maintaining desirable quality of yield given that the sexual propagation may genetically transfer undesirable traits. Grafting can also be a desirable method to propagate plants which are hard to root such as Siberian pine (e.g., Severova, 1958; 1968; Kolegova, 1977). However, a problem of incompatibility between grafted parts may occur and result in a further dieback of a plant. Thus, it is of importance to know mechanisms of incompatibility between parts of the graft to mitigate the potential problem even before planting the grafts or reduce the size of the effect. Also, recent literature has lots of information about transfer of desirable and undesirable traits. Summarizing of this information might be useful for forest services. Thus, the objective of this paper was to review the recent literature related to graft applications and incompatibility between scion and rootstock.

\section{Types of grafts}

Grafting occurs naturally that might involve branches or more often roots of the same species (inosculation) (e.g., Janick, 2009), or artificially via asexual propagation where the tissues of two plants are encouraged to fuse with one another. Artificial grafting is often used for propagation to improve qualities of trees via selecting for its roots (called the rootstock) and for other characteristics such as stem, leaves, flowers or fruits (called the scion).

Natural root grafting happens when roots of plants make physical contact with each other, while branch or trunk grafting may occur when crossed branches become in a close contact in a dense stand in which bark might become injured by fusion due to their friction under the air movements (e.g., winds) (e.g., Pravdin, Nekrasov, 1953). Although natural grafting is common between tree of the same species it has been also observed for trees of different species but the same genus. Natural grafting is common for holly, lime, oak, beech, Scots pine and Jack pine (e.g., Pravdin, Nekrasov, 1953; Janick, 2009). Natural grafting might affect ecosystems negatively by possible transmission of tree pathogens (Epstein, 1978) or positively through sharing water and nutrients via root grafts (e.g., Bormann, 1966), by providing support for a weaker tree, and an adaptation to promote fire or wind resistance (e.g., Loehle, Jones, 1990). A study demonstrated that root grafts can be less impacted by hurricane damage compared to non-grafted trees (Basnet et al., 1993). Another study demonstrated that grafted shaded trees had significantly higher root nonstructural carbohydrate concentrations than non-grafted shaded trees, indicating that root grafts partially offset the effects of shading (Fraser et al., 2006). A recent study demonstrated that after thinning, a growth increment was much less for trees, which had root grafts with removed trees, and it was linked to the support of roots and stamps by live residual trees (Tarroux et al., 2010). Keeley (1988) hypothesized that root grafts would be of selective advantage to dominants regardless of the status of the tree to which it is grafted. For example, grafts would be of selective value in waterlogged soils because they would enhance anchorage effect by dispersing the tree's compressive force over a greater surface area.

Grafts can be classified as homografts if the scion and rootstock are of the same species or heterografts if they are of different species. Several studies demonstrated that functioning and growth of homografts is often more successful compared to heterografts because of higher similarities in genetic structure between the graft components (Kovalishin, 1966; Yakovleva, 1967, 1974, 1975). Although heterografts more often experience incompatibility because of the differences in 
anatomy, morphology and physiology between the graft components, they could be more beneficial than homografts. Heterografts of Pinus sibirica Du Tour demonstrated a higher growth compared to homografts (Matveeva and Kichkildeev, 2006). Grafting of flood-sensitive Annona species onto A.glabra rootstock improved flood tolerance of the species (Nuñez-Elisea et al., 1999). Grafting Fraser fir onto Turkish fir demonstrated reduced losses by phytophtora root rot in the southern Appalachian Mountains of North Carolina (Hibbert-Frey et al., 2006). Fig grafts showed an improved growth response to nematodes, which varied depending upon a rootstock (Hosomi et al., 2002).

\section{Grafts applications}

Grafts are often used in agriculture to reduce the time to flowering and shorten the breeding program, improve quality and yield of seeds and fruits, improve hardiness in response to environmental conditions and pathogens resistance and change cultivars (Severova, 1958; Kovalishin, 1968; Browning, Watkins, 1991; Titov, 1993; 1995; Lahav et al., 1995; Hosomi et al., 2002; Sanou et al., 2004; Giorgi et al., 2005; Hibbert-Frey et al., 2006; Ahmed et al., 2006; Mitani et al., 2008; Cantin et al., 2010; Gandev, 2009; Franzon et al., 2010; Bellefontaine et al., 2010; Pio et al., 2010; Souza et al., 2010; Tandonnet et al., 2010). For example, for Siberian pine it could take two-three years after grafting to develop reproductive organs strobills, and about 30-40 years for a sexually-propagated plant. Correspondingly, it could take 20 years for grafts and 170-240 years for sexually-propagated Siberian pines to reach the maximum seed production of (Severova, 1958; Beh et al., 2009). Also, Siberian pine/Scots pine heterografts had a higher growth and height compared to Siberian pine homografts (Matveeva, Kichkildeev, 2006). Another study by Browning and Watkins (1991) tested several new quince hybrid rootstocks for pears and demonstrated that they all differed in their influence on fruit production and quality. A study of citrus hybrid seedlings grafted into shiikuwasha (Citrus depressa Hayata) demonstrated that about one third of the plants flowered two and a half years after grafting, while usually it takes almost 20 years from crossing to cultivar release to the industry (Mitani et al., 2008).

Several studies also demonstrated effect of rootstock on branching (e.g., Jayawickrama et al., 1991; Hirst, Ferree, 1995), crown, size and chemical content of leaves (Jayawickrama et al., 1991), fruit size and weight, rind thickness, juice content, brix, total acids and brix: acid ratio (Girogi et al., 2005; Ahmed 2006; Georgiou, 2009), and flavonoid content (Gil-Izquierdo et al., 2004). Grafting is often used to induce dwarfing to apple trees or other orchards because it increases productivity by providing more fruits per unit of land and higher quality of fruits (e.g., Sitarek, 2006; Prassinos et al., 2009). One of the explanations is that when inducing dwarfing in grafts it results in shift in resource allocation towards reproductive organs compared to shoot growth (Webster, 1995).

Rootstock effects on plants have not always been positive. For example, Cardinal et al. (2007) demonstrated that yield of Hevea brasiliensis varied from $41 \%$ to $86 \%$ depending upon genetic background of a rootstock. Another study demonstrated that selection of a rootstock or scion might suppress yield and growth of apple trees (Univer et al., 2006). A recent study suggested that scion might also affect root vigour of a rootstock which was not related to carbon supply from the shoot (Tandonnet et al., 2010).

\section{Scion-rootstock interaction}

Grafts represent two different genetic identities functioning as two systems in one 
organism influencing each other. Understanding about mechanisms of the rootstock-scion interaction is yet limited. Several studies demonstrated mechanisms of scion-rootstock interaction on grafts, which were used to induce dwarfing. One of the hypotheses is that the growth regulator, auxin, which is transported at different rates between grafts on different rootstocks, affects cytokinin production in roots and causes differences in shoot growth (Lockhard, Schneider 1981; Webster 1998). Another hypothesis assumes that phenols accumulating at the graft union reduce tissue viability and the rate of auxin breakdown (Lockard, Schneider 1981, Treutter, Feucht 1991, Errea et al., 1994). Finally, the rootstock-induced dwarfing is caused by reduced soluble transport across the graft union (Atkinson et al., 2003, Basile et al., 2003). In addition, Prassinos and coauthors (2009) showed that rootstock-induced dwarfing might be caused by differential cessation of terminal meristem growth and is triggered by rootstock-specific gene regulation.

Most of studies demonstrated that there is no horizontal gene transfer between the graft components, scion and rootstock. However, a recent study of grafted tobacco plants demonstrated exchange of genetic information via either large DNA pieces or entire plastid genomes (Stegemann, Bock, 2009). In this study, the analysis of the graft sites revealed the frequent occurrence of cells harboring both antibiotic resistances and both fluorescent reporters. Although this research showed the exchange of genetic material between grafted components, the gene transfer was only restricted to the contact zone between the grafted components, which indicated that the changes could become heritable only via lateral shoot formation from the graft site. Previously, there was a study that described hereditary changes in grafted pepper, and suggested that these changes might be induced by a mechanism similar to that of transformation in higher organisms (Ohta, Van Chuong, 1975). Yet, there are unresolved issues of whether gene transfer depends on the cell contacts between scion and rootstock. Although micromolecules can go through plasmodesmata, it is unknown if plastids or macromolecules of DNA can go through the plasmodesmata considering that their anatomical structure can change due to specific proteins.

\section{Incompatibility between scion and rootstock}

Incompatibility between rootstock and scion has been more often observed for interspecific than intra-specific grafts, which might further result in a dieback of a graft. Anatomical studies of incompatible grafts demonstrated a poor vascular connection, vascular discontinuity and phloem degeneration at the union area, which might be detected as early as few weeks after a graft establishment (Pina, Errea, 2005; Pina et al., 2009). This results in a disturbance of water and nutrients transfer by xylem in one direction and photoassimilates by phloem in another direction. Plasmodesmata are important communication pathways in plants (e.g, Pina et al., 2009). These are channels in the plant cell wall allowing passage of macromolecules and solutes between the neighboring cells. A recent study demonstrated that insufficient plasmodesmatal coupling at an early stage of development within one of the graft partners might result in graft incompatibility (Pina et al., 2009).

At the graft connection area a callus forms as a reaction to wounding. Another study of apricot grafted onto a plum rootstock demonstrated that only some callus differentiation into cambium and vascular tissues occurred; while a large portion of the callus never differentiated (Pina, Errea, 2005). This interrupts the vascular connections because of the lack of differentiation that brings discontinuities in the cambium and 
the formation of a band of parenchymatous cells. In a study of pear grafts typical symptoms of graft incompatibility such as bark discontinuity, cambial dysfunction and accumulation of starch in the scion were observed. Little cell necrosis was observed at the interface of incompatible grafts at the 5-month stage of graft development (Ermel et al., 1999). In spite of a lack of scion/stock vascular connections, some plants demonstrated that they could flower and produce seeds, i.e., there were nonvascular functional connections between the two plants, probably of parenchyma cells (Flaishman et al., 2008). Abundance of periderm rings was also a symptom of incompatibility according to a study by Ermel et al. (1999), which were more abandoned in incompatible grafts. In some cases, signs of incompatibility have been revealed a few years after grafting and were explained by differences in radial growth between scion and stock that breaks tissue connectivity at the graft union (Savva et al., 2004).

In a study of peach/plum grafts it has been demonstrated that free amino acids per tree decreased in rootstock of incompatible grafts while they became stabilized in compatible grafts between 79-89 days after grafting (Moreno et al., 1994). Another study of peach/plum grafts by Moing and Gaudillere (1992) demonstrated that sorbitol was lower in roots of incompatible grafts compared to compatible ones, and that sugars and starch accumulated in scions of the incompatible grafts following 78 days after grafting, but carbon partitioning was only slightly affected by graft incompatibility. They also showed that nitrogen assimilation ceased 78 days after grafting in incompatible grafts, which was not the case in compatible grafts. This suggested an inhibited transport of solubles from roots to scion in rootstocks and from photosynthetic apparatus to rootstock. A study of pear/quince grafts demonstrated that $63 \mathrm{kDa}$ protein might be responsible for incompatibility because it was observed in compatible grafts, faintly observed in intermediate compatible grafts and was not detected in incompatible grafts (Gulen et al., 2005), Absence of peroxidase $A$ in pear/quince grafts has been also related to graft incompatibility (Hossein et al., 2008).

Graft incompatibility can be often determined at an early stage of graft development. For example, in a study of apricot grafts accumulation of phenol compounds could serve as an indicator of incompatibility as early as the first week after grafting (Errea et al., 2001). Another study also indicated that accumulation of phenol deposits at the place of graft union might inhibit graft compatibility (Mng'omba et al., 2008). Another study also demonstrated that differences in phenol accumulation below and above the graft union might serve as an indicator of compatibility (Usenik et al., 2006). Additionally, a study of Prunus persicu/Prunus spp. grafts indicated that significant increase in peroxidase activity might be observed in incompatible unions (Zarrouk, 2010).

\section{Conclusion}

Our literature review demonstrated that there are varieties of grafts which might inherent desirable or undesirable properties from their graft components. Incompatibility is a complex problem that might occur between graft plants and result in their further dieback. Here, we reviewed and discussed several mechanisms of graft incompatibility, and concluded that compatibility might be improved by selection of the types of rootstock and scion that might: (1) favor callus differentiation into cambium and vascular tissues; (2) be able to establish a close cell contact at the graft union to maintain water and nutrient balance between scion and rootstock; and (3) enable synchronicity in radial growth and cell differentiation between scion and rootstock. Graft 
components with similar genetic backgrounds might be incompatible less often compared to inter-specific grafts. Biochemical markers such as abundance of phenol compounds and starch at the union, below and above the union and specific polypeptide, peroxidase activity might be helpful to diagnose incompatibility at an earlier stage of graft development.

\section{Acknowledgements}

The authors would like to acknowledge the support provided to the 2010 winners of the Russian Federation government support to the leading scientific schools (grant №HW65610.2010.4). We are also grateful to the grant No. 53 of the Siberian Branch of the Russian Academy of Sciences for partial support.

\section{References}

Ahmed W., Pervez M.A., Amjad M. et al. (2006) Effect of stionic combination on the growth and yield of kinnow mandarin (Citrus reticulata blanco). Pak. J. Bot. 38(3): 603-612.

Atkinson C.J., Else M.A., Dover C.J. (2003) Root and stem hydraulic conductivity as determinants of growth potential in grafted trees of apple (Malus pumila Mill.). J. Exp. Bot. 54: 1221-1229.

Basile B., Marsal J., DeJong T.M. (2003) Daily shoot extension growth of peach trees growing on rootstocks that reduce scion growth is related to daily dynamics of stem water potential. Tree Physiol. 23: 695-704.

Basnet K., Scatena F.N., Likens G.E., Lugo A.E. (1993) Ecological consequences of root grafting in Tabonuco (Dacryodes excelsa) trees in the Luquillo Experimental Forest, Puerto Rico. Biotropica 25(1): 28-35.

Beh I.A., Krivets S.A., Bisirova E.M. (2009) Kedr-zhemchuzhina Sibiri (Siberian pine is a pearl of Siberia). Tomsk: Pechatnaya manufaktura, 50 p. (in Russian).

Bellefontaine R., Ferradous A., Alifriqui M. et al. (2010) Vegetative propagation of argan tree, argania spinosa in morocco. The john goelet project bois et forets des tropiques 304: 47-59.

Bormann F.H. (1966) Structure, function and ecological significance of root grafts in Pinus strobus L. Ecol. Monographs 36(1): 1-26.

Browning G., Watkins R. (1991) Preliminary evaluation of new quince (Cydonia oblonga Miller) hybrid rootstocks for pear. J. Hort. Sci. 66: 35-42.

Callow J. A. (1996) Advances in Botanical Research. London: Academic Press, 328 p.

Cantin C.M., Pinochet J., Gogorcena Y. et al. (2010) Growth, yield and fruit quality of 'Van' and 'Stark Hardy Giant' sweet cherry cultivars as influenced by grafting on different rootstocks Scientia Hort. 123(3): 329-335.

Cardinal A.B.B, Goncalves P.D.S, Martins A.L.M. (2007) Stock-scion interactions on growth and rubber yield of Hevea brasiliensis. Scientia Agricola 64(3): 235-240.

Epstein A.H. (1978) Root graft transmission of tree pathogens. Ann. Rev. Phytopathol. 16: 181-92.

Ermel F.F., Kervella J., Catesson A.M., Poëssel J.L.V. (1999) Localized graft incompatibility in pear/quince (Pyrus communis/Cydonia oblonga) combinations: multivariate analysis of histological data from 5-month-old grafts. Tree Physiol.19: 645-654.

Errea P., Felipe A., Herrero M. (1994) Graft establishment between compatible and incompatible Prunus spp. J. Exp. Bot. 45: 393-401.

Errea P., Garay L., Marin J.A. (2001) Early detection of graft incompatibility in apricot (Prunus armeniaca) using in vitro techniques. Physiologia Plantarum 112(1) 135-141. 
Flaishman M.A., Loginovsky K., Golobowich S., Lev-Yadun S. (2008) Arabidopsis thaliana as a model system for graft union development in homografts and heterografts. J. Plant Growth Regul. 27: 231-239.

Franzon R.C., Goncalves R.D., Antunes L.E.C. et al. (2010) Vegetative propagation of surinam cherry (Eugenia uniflora l.) genotypes from southern brazil, through cleft graft. Revista brasileira de fruticultura 32(1): 262-267.

Fraser E.C., Lieffers V.J., Landhausser S.M. (2006) Carbohydrate transfer through root grafts to support shaded trees. Tree Physiol. 26: 1019-1023.

Gandev S. (2009) Propagation of walnut (Juglans regia L.) under controlled temperature by the methods of omega bench grafting, hot callus and epicotyl grafting Bulgarian J. Agr. Sci. 15(2): 105108 .

Georgiou A. (2009) Evaluation of rootstocks for the Cyprus local lemon variety 'Lapithkiotiki.' Scientia Hort. 123(2): 184-187.

Gil-Izquierdo A., Riquelme M.T., Porras N. et al. (2004) Effect of the rootstock and interstock grafted in lemon tree (Citrus limon (L.) Burm.) on the flavonoid content of lemon juice. J. of agricultural and food chemistry 52(2): 324-331.

Giorgi M., Capocasa F., Scalzo J. at al. (2005) The rootstock effects on plant adaptability, production, fruit quality, and nutrition in the peach (cv. "Suncrest"). Scientia Hort. 107: 36-42.

Gulen H., Kuden A., Postman J., Arora R. (2005) Total protein content and SDS-page in pear scions grafted on quince a and pear seedling rootstocks. Turk. J. Agr. For. 29: 91-96

Hibbert-Frey H., Frampton J., Blazich F.A. et al. (2010) Grafting Fraser Fir (Abies fraseri): Effect of Grafting Date, Shade, and Irrigation. Hort. Sci. 45(4): 617-620.

Hirst P.M., Ferree D.C. (1995) Effect of rootstock and cultivar on the growth and precocity of young apple-trees. Fruit Var. J. 49(1): 34-41.

Hosomi A., Dan M., Kato A. (2002) Screening of fig varieties for rootstocks resistant to soil sickness. J. of the Japanese Society for Hort. Sci. 71(2): 171-176.

Hossein D.G., S. Farajollah, H. Hassanpour (2008) Identification of graft incompatibility of pear cultivars on quince rootstock by using isozymes banding pattern and starch. Asian J. Plant Sci. 7: 109112 .

Iroshnikov A.I. (1985) Bioekologicheskie svoystva i izmenchivosty kedra sibirskogo. Kedrovye lesa Sibiri. Novosibirsk: Nauka, 8-40 pp. (in Russian).

Janick J. (2009) Horticultural reviews V.35. New Jersey: John Wiley \& Sons, Inc., 531 p.

Jayawickrama K.J.S., Jett J.B., Mckeandz S.E. (1991) Rootstock effects in grafted conifers: A review. New Forests 5: 157-173.

Keeley J.E. (1988) Population variation in root grafting and a hypothesis. Oikos 52(3): 364366.

Kolegova N.F. (1977) Geographicheskie privivochnye plantacii sosny i kedra v Krasnoyarskoi lesostepi. V: Geographicheskie kultury i plantacii hvojnich v Sibiri (Graft provenance plantations of Scots and Siberia pine in Krasnoyarsk forest-steppe. In: Provenance and other forest plantations of coniferous in Siberia). Novosibirsk: Nauka, SB AS USSR, 154-166. (in Russian).

Kollmann R., Glockmann C. (1985) Studies on graft unions. 1. Plasmodesmata between cells of plants belonging to different unrelated taxa. Protoplasma 124: 224-235. 
Kovalishin F.P. (1966) Mezchvidovye I mezchrodovye privivki hvoynyh porod. Lesohozyaystvennaya informaciya. Moskva: CBNTIleshos, V.4: 1-2 (in Russian).

Kovalishin F.P. (1968) Sozdanie semennyh plantaciy listvennicy privivkoy. Lesnoe hosyaystvo 2: 56-58 (in Russian).

Kuznetsova G.V. (2003) Semenoshenie i kachestvo semyan klonov kedra sibirskogo raznogo proishozhdeniya na plantacii v Krasnoyarskoi lesostepi. (Quality of seeds of clones of Siberian pine grafts of different provenances in Krasnoyarsk forest-steppe). Lesovedenie 6: 42-48. (in Russian).

Lahav E., Tomer E., Gazit S., Lavi U. (1995) Performance of avocado (Persea americana Mill.) and mango (Mangifera indica L.) seedlings compared with their grafted trees. J. Amer. Soc. Hort. Sci. 120(2): 265-269.

Loehle C., Jones R. (1990) Adaptive significance of root grafting in trees. Functional Ecol. 4(2): 268-271.

Lockhard R.G., Schneider G.W. (1981) Stock and scion growth relationships and the dwarfing mechanisms in apple. Hort. Rev. 3: 315-375.

Matveeva R.N., Kichkildeev A.G. (2006) Intensivnost rosta 18-letnego privitogo kedra sibirskogo (klon 91/55) v zavisimosti ot vida podvoya (Growth rate of 18 year old Siberian pine grafts depending upon scion). Hvojnie borealnoj zony 23(2): 220-222. (in Russian).

Mitani N., Matsumoto R., Yoshioka T. et al. (2008) Citrus hybrid seedlings reduce initial time to flower when grafted onto shiikuwasha rootstock. Scientia Hort. 116(4): 452-455.

Mng'omba S. A., du Toit E. S., Akinnifesi F.K. (2008) Early recognition of graft compatibility in Uapaca kirkiana Muell Arg. clones, provenances and species. Agroforest. Syst. 74: 173-183.

Moing A., Carbonne F., Gaudillere J.P. (1990) Growth and carbon partitioning in compatible and incompatible peach/plum grafts. Physiol. Plant. 79: 540-546.

Moing A., Gaudillere J.P. (1992) Carbon and nitrogen partitioning in peach/plum grafts. Tree Physiol. 10: 81-92.

Moreno M.A., Gaudillere J.P., Moing A. (1994) Protein and amino acid content in compatible and incompatible peach/plum grafts. J. Hort. Sci. 69(6): 955-962.

Nuñez-Elisea R., Schaffer B., Fisher J. et al. (1999) Influence of flooding on net $\mathrm{CO}_{2}$ assimilation, growth, and stem anatomy of Annona species. Ann. Bot. 74: 771-780.

Pina A., Errea P. (2005) A review of new advances in mechanism of graft compatibility incompatibility. Scientia Hort. 106(1): 1-11.

Pina A., Errea P., Schulz A., Martens H.J. (2009) Cell-to-cell transport through plasmodesmata in tree callus cultures. Tree Physiol. 29: 809-818.

Pio R., Chagas E.A., Barbosa W. et al. (2010) Production of quince nursery trees by different grafting methods. Ciencia Rural 40(5): 1049-1052.

Prassinos K., Ko J.-H., Lang G. et al. (2009) Rootstock-induced dwarfing in cherries is caused by differential cessation of terminal meristem growth and is triggered by rootstock-specific gene regulation. Tree Physiol. 29: 927-936.

Pravdin L.F., Nekrasov V.I. (1953) Samoprivivki hvojnih drevesnih porod (Natural graft of woody plants). Bot. Zhyrnal 38(6): 874-878. (in Russian).

Treutter D., Feucht V. (1991) Accumulation of phenolic compounds above the graft union of cherry trees. Gartenbauwissenchaft 56: 134-137. 
Sanou H., Kambou S., Teklehaimanot Z. et.al. (2004) Vegetative propagation of Vitellaria paradoxa by grafting. Agroforest. Syst. 60(1): 93-99.

Savva Y.V., Yakovleva A.Y., Vaganov E.A, Kuznetsova G.V. (2004) Reakciya privivok kedra sibirskogo na izmeneniya klimaticheskih faktorov (Response of Siberian pine grafts to climate variability). Lesnoe hozyajstvo 5: 36-38. (in Russian).

Schaffer B., Davies F.S., Crane J.H. (2006) Responses of subtropical and tropical fruit trees to flooding in calcareous soil. Hortscience 41(3): 549-555.

Severova A.I. (1958) Privivki kedra sibirskogo na sosne (Siberian pine/ Scots pine grafts. Institute lesa). AS USSR 3-8 (in Russian).

Severova A.I. (1968) Semenosheniye privivok hvojnih porod (Seeds of coniferous grafts). Lesnoe hozyajstvo 2: 58 - 62 (in Russian).

Sitarek M. (2006) Incompatibility problems in sweet cherry trees on dwarfing rootstocks agronomijas vēstis. Lat. J. of Agr. 9: 140-144.

Souza E.P., Mendonca R.M.N., Silva S.D. et al. (2010) Grafting of yellow mombin tree. Revista brasileira de fruticultura 32(1): 316-320.

Stegemann S., Bock R. (2009) Exchange of genetic material between cells in plant tissue grafts. Science 324(5927): 649 - 651.

Tandonnet J.-P., Cookson S.J., Vivin P., Ollat N. (2010) Scion genotype controls biomass allocation and root development in grafted grapevine. Austr. J. of Grape and Wine Research 16: 290-300.

Tarroux E., DesRoches A., Krause C. (2010) Effect of natural root grafting on growth response of jack pine (Pinus banksiana) after commercial thinning. Forest Ecology and Management 260: 526-535.

Titov E.V. (1993) Sozdanie spezializirovannyh orehoplodnyh privivochnyh plantaciy sosny kedrovoy sibirskoy. (Creating of seed production specialized graft plantations of Siberian pine). V: Sosnovye lesa Rossii v sisteme mnogocelevogo ispolyzovaniya P.115-117 (in Russian).

Titov E.V. (1995) Selekciya sosny kedrovoy sibirskoy na semennuyu produktivnosty. (Selection of Sibirian pine for seed production). Avtoref. diss. na soiskanie uchenoy stepeni d.s.-h. n. Bryansk, 43 pp. (in Russian).

Univer N., Univer T., Tiirmaa K. (2006) Effect of five rootstocks on growth and yield of four apple cultivars in young orchard. Scientific works of the Lithuanian Institute of Horticulture and Lithuanian University of Agriculture 25(3): 192-198.

Usenik V., Krska B., Vican M., Stampar F. (2006) Early detection of graft incompatibility in apricot (Prunus armeniaca L.) using phenol analyses. Scientia Horticulturae 109: 332-338.

Ohta Y., Van Chuong P. (1975) Hereditary changes in Capsium-annuum. 1. Induced y ordinary grafting. Euphytica 24: 355-368.

Webster A.D. (1995) Rootstock and interstock effects on deciduous fruit tree vigour, precocity, and yield productivity. New Zealand J. Crop and Hort. Sci. 23: 373-382.

Webster A.D. (1998) Strategies for controlling the size of sweet cherry trees. Acta Hortic. 468: 229-239.

Yakovleva L.V. (1967) Opyt mezchvidovoy i mezchrodovoi privivki hvoynyh porod. Trudy botanicheskogo sada 6: 23-25 (in Russian).

Yakovleva L.V. (1974) Issledovanie privivok hvoynyh porod. Trudy botanicheskogo sada 63: 9397 (in Russian). 
Yakovleva L.V. (1975) Otdalennaya privivka v otkrytom grunte. V: Genetica, selekciya, semenovodstvo i introdukciya lesnyh porod. Moskva, 206-214 (in Russian).

Zarrouk O., Testillano P.S., Risueño M.C. et al. (2010) Changes in cell/tissue organization and peroxidase activity as markers for early detection of graft incompatibility in peach/plum combinations. J. Amer. Soc. Hort. Sci. 135: 9-17.

\title{
Прививки древесных растений
}

\section{и проблема несовместимости подвоя}

и привоя (обзор)

\author{
Ю.А. Дарикова ${ }^{a}$ Ю.В. Савва ${ }^{a}$ Е.А. Ваганов ${ }^{a}$, \\ А.М. Грачев ${ }^{a}$, Г.В. Кузнецова ${ }^{\sigma}$ \\ ${ }^{a}$ Сибирский федеральныий университет, \\ Россия 660041, Красноярск, пр. Свободный, 79

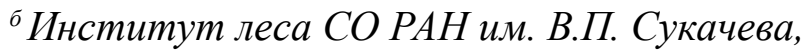 \\ Россия 660036, Красноярск, Академгородок, 50
}

\begin{abstract}
Прививки древесных растений могут возникать естественным образом в результате срастания стволов или корней деревьев, находящихся в тесном контакте друг с другом, или искусственно, при пересадке части одного растения, называемого привоем, на другое - подвой. Прививание растений применяется для повышения продуктивности, улучшения качества плодов, ускорения наступления плодоношения, а также повышения резистентности $к$ неблагоприятным факторам среды и патогенам. Из двух видов прививок-гомопластические (внутривидовые) и гетеропластические (межвидовые) - проблемы, связанные с анатомофизиологической несовместимостью, чаще всего возникают у последних. Целью данной статьи является обзор современной литературы, связанной с применением прививания и проблемой несовместимости между компонентами прививки. На анатомическом уровне несовместимость представляет собой нарушение целостности васкулярных элементов, прерывающихся слоем некротических клеток в зоне контакта привоя и подвоя. В физиологическом отнотении неполноценный межклеточный контакт создает барьер, препятствующий доступу воды и минеральных веществ в верхнюю часть растения - привой, и ассимилятов - в противоположном направлении. Несовместимость может быть также результатом нарушения формирования плазмодесм на ранней стадии развития прививки. Различие в концентрации фенольных соединений и крахмала, их избыток ниже и выме зоны срастания компонентов прививки, так же как и пероксидаз, может служить биохимическим маркером несовместимости между привоем и подвоем. Последствия несовместимости привоя и подвоя угнетают рост растения и являются причиной его гибели. Подбор генетически и биохимически сходных компонентов прививки может минимизировать проблему несовместимости.
\end{abstract}

Ключевые слова: привой, подвой, прививание, совместимость. 